See discussions, stats, and author profiles for this publication at: https://www.researchgate.net/publication/341108663

Towards a theory of integrated empowerment: a service ecosystems agenda for future

Article · May 2020

DOI: 10.1504/IJQRS.2020.10031947

CITATIONS

2 authors:

Milind Mandlik

University of Auckland

6 PUBLICATIONS 3 CITATIONS

SEE PROFILE
READS

93

Djavlonbek Kadirov

Victoria University of Wellington

50 PUBLICATIONS 347 CITATIONS

SEE PROFILE

Some of the authors of this publication are also working on these related projects:

Project brand name and slogan extension tendencies View project 


\title{
Towards a theory of integrated empowerment: a service ecosystems agenda for future
}

\author{
Milind A. Mandlik* \\ Department of Marketing, \\ University of Auckland, \\ Auckland 1010, New Zealand \\ Email: m.mandlik@auckland.ac.nz \\ *Corresponding author
}

\section{Djavlonbek Kadirov}

The School of Marketing and International Business, Victoria University of Wellington, Wellington 6011, New Zealand Email: djavlonbek.kadirov@vuw.ac.nz

\begin{abstract}
This paper broadens the current understanding of the empowerment phenomenon within the service ecosystems framework. We reviewed and critically analysed extant literature on empowerment theory and noted that the micro-level conceptualisation of empowerment heavily relies on forms of power grab/power share/power transfer to achieve outcomes of power symmetry, also called the state of empowerment. We go beyond current understanding of empowerment as a micro-level (enabling) phenomenon, proposing and arguing for a macro-level conceptualisation, coined integrated empowerment, in which each entity/participant within a given ecosystem is imparted with the required autonomy (power) to participate in a way that enhances overall health of the service ecosystem. Integrated empowerment creates/constructs episodes of service provisioning, and service provisioning is only possible because of integrated empowerment. This paper prompts future research exploring the concept of integrated empowerment and contributes to current understanding of the empowerment phenomenon and its integral role in service provisioning.
\end{abstract}

Keywords: consumer empowerment; integrated empowerment; service ecosystems; service dominant logic.

Reference to this paper should be made as follows: Mandlik, M.A. and Kadirov, D. (2020) 'Towards a theory of integrated empowerment: a service ecosystems agenda for future', Int. J. Qualitative Research in Services, Vol. 4, No. 1, pp.56-76.

Biographical notes: Milind A. Mandlik is a Teaching Fellow in Marketing at the Department of Marketing, University of Auckland Business School. He received his $\mathrm{PhD}$ in Marketing from the University of Waikato in New Zealand. He understands and explores human behaviour through physiological, sociological and psychological processes fascinated by the ever-changing intricacies of human behaviour and its influence on consumption choices. 
Djavlonbek Kadirov is a Lecturer in Marketing at the Victoria University of Wellington, New Zealand. He received his $\mathrm{PhD}$ in Marketing from the University of Waikato in New Zealand and MSc in Marketing with distinction from the Salford University in UK. His research interests include marketing systems, marketing and society, sustainable marketing, and authentic brands. His research has appeared in journals such as the Journal of Macromarketing, Journal of Marketing Management, Journal of Business Research and Consumption Markets and Culture.

\section{Introduction}

In this article, we offer the results of a conceptual examination of the empowerment phenomenon from a macro perspective. Empowerment, especially as it is interpreted at the micro level, has been an intriguing and challenging subject within evolving academic thought (Akhavannasab et al., 2018; Bekin et al., 2006; Ben Ayed and El Aoud, 2017; Conger and Kanungo, 1988; Holosko et al., 2001; Ioannidou, 2018; Ramani and Kumar, 2008). The evolution of empowerment-related thought in business disciplines has tracked the route of micro-to-meso-to-macro, reflecting similar trends in other disciplines (Castelfranchi, 2003). Conceptually, empowerment was first positioned as an intra-firm process/outcome signifying 'improved employee autonomy' within the context of employer-employee relationships, but it soon transcended the boundaries of the firm to encompass manager-employee-customer relationships (Bowen and Lawler, 1995). Later, the concept led to the development of thought on 'improved customer autonomy' (Bernoff and Schadler, 2010; Boyd et al., 2014; Denegri-Knott et al., 2006; Füller et al., 2009; Mandlik et al., 2014; Watheiu et al., 2002). However, in light of recent arguments put forth within the service ecosystems framework in the service sectors of the economy (Chandler and Vargo, 2011; Frow et al., 2014; Lusch et al., 2010; Wieland et al., 2012), we believe that the understanding of the empowerment phenomenon must evolve further.

Within the service ecosystems framework, a clear separation between producers and consumers is questioned, and thus the assumption of service providers (imbued with power) empowering 'powerless' employees and/or consumers is a hardly conceivable viewpoint. The understanding of the phenomenon of empowerment within service ecosystems requires a holistic approach underscored by systems thinking, rather than by a mechanistic approach based on analysis of separate parts of the very system designed to enable empowered outcomes (von Bertalanffy, 1950). Taking these service ecosystems insights into account, there are two different perspectives of the empowerment phenomenon that can be outlined in the context of service encounters: the traditional view and the integrated empowerment view. The traditional view encompasses extant knowledge about the empowerment phenomenon to date, and the integrated empowerment view encompasses synthesised suggestions for how the concept should be seen from the service ecosystems perspective.

Extant literature on the traditional view suggests that the behaviour of a market actor (e.g., a service provider) is predominantly driven by self-interest, whereby the actor strives to improve its own efficacy, mastery, and capacity to act in order to achieve a 
variety of outcomes (e.g., economic or other outcomes). In contrast, the integrated (service-ecosystems based) view is concerned for the development of the whole service ecosystem, within which the resource integrators interactively engage with other service providers to foster their capabilities to provide services that are in turn used as input resources for value co-creation opportunities (Barile et al., 2016; Wieland et al., 2012). Within the service ecosystems perspective, such enablement is conceived to be mutually driven, imparting beneficial outcomes for all of the intermediaries (or stakeholders) throughout the entire ecosystem (Frow et al., 2014). This paper proposes the notion of integrated empowerment as a process/outcome which is directed at maximising the autonomy of the resource integrators (i.e., service ecosystem participants). Hence, from a macro perspective, empowerment refers to the very processes/outcomes that enable service provisioning.

To justify this proposal, this paper begins with a brief overview of different conceptualisations of the empowerment phenomenon. Empowerment, in its various forms and meanings, has been studied across many disciplines for more than three decades. The brief overview of conceptual perspectives on empowerment highlights that the concept has been understood differently by researchers in different contexts. Additionally, it illustrates that while there are subtle differences among fundamental empowerment themes, under recent conceptualisation, there is an overwhelmingly evident core theme of empowerment as an enabled phenomenon. Next, this paper presents an overview of empowerment perspectives in marketing and consumption studies, followed by explanation of the interpretive frames we used for our critical analysis of empowerment literature through the service ecosystems perspective. The paper then proceeds with challenging the current understanding of the empowerment phenomenon, particularly when viewed through the lens of the service ecosystems perspective, and discusses the concept of integrated empowerment.

\section{Conceptual perspectives on empowerment}

From early on, there has been a consensus that empowerment as a phenomenon has two etymological meanings: the process of becoming empowered, and the outcome of such processes or the state of being empowered (Schulz et al., 1995). As Zimmerman (1995) states, "it is useful to distinguish between empowering processes and empowered outcomes because the former refers to how people, organisations, and communities become empowered, whereas the latter refers to the consequences of the processes" (p.583). Although few researchers held the rare view that empowerment should only be studied by investigating the outcomes of the process and not the process itself (Christens, 2012), we see both meanings as two sides of the same coin. In brief, each discipline conceptualises the phenomenon of empowerment differently, while discussions on the nature of power and scope (e.g., micro versus macro) remain central for all of them. Whether the process of empowerment ends up with an empowered or disempowered outcome depends entirely on the various opportunities and stances taken by the social actors (e.g., individuals, enterprises, communities, and socio-political entities). The key is in how these actors interact with others when given an opportunity to share resources, 
enhance skills and abilities, and participate in collective action to bring about meaningful changes in the lives of all the social actors involved in the process. The review of this literature led to distinguishing four meanings or interpretations of empowerment as a phenomenon: authorisation-based empowerment, structural empowerment, reciprocal empowerment and integrated empowerment (Table 1).

Table 1 Empowerment matrix

\begin{tabular}{|c|c|c|c|}
\hline & & \multicolumn{2}{|c|}{ MEANINGS OF EMPOWERMENT } \\
\hline & & Power transfer & Mutual enhancement \\
\hline \multirow[t]{4}{*}{ SCOPE } & Micro & Authorisation-based empowerment & Reciprocal empowerment \\
\hline & \multirow{3}{*}{ Macro } & $\begin{array}{l}\text { (power is invested in the powerful; } \\
\text { the powerful, involuntarily or under } \\
\text { pressure, transfer power to the } \\
\text { powerless) }\end{array}$ & $\begin{array}{l}\text { (the use of power to enhance } \\
\text { another's power, driven by } \\
\text { values of equality, benevolence, } \\
\text { and reciprocity) }\end{array}$ \\
\hline & & Structural empowerment & Integrated empowerment \\
\hline & & $\begin{array}{l}\text { (environmental changes create } \\
\text { unanticipated transfer of power) }\end{array}$ & $\begin{array}{l}\text { (contextual, entangled, } \\
\text { relativistic power advantages are } \\
\text { mutually invested to enhance } \\
\text { system-wide efficacy) }\end{array}$ \\
\hline
\end{tabular}

Authorisation-based empowerment assumes 'power' to be a valuable substance (e.g., capital) that can be transferred from one individual or group to another. Here, the scope is within the micro level as it is believed that such power is invested within the powerful who can fully or partially authorise its use by others. In contrast, the scope of structural empowerment is within the macro level, and this interpretation assumes that power transfer occurs due to unanticipated changes in the environment (e.g., in the institutional context), irrespective of whether it was authorised by parties in power. It is assumed that respective power levels undergo changes because of evolving changes in the environment. Reciprocal empowerment assumes that actors operating at the micro level mutually enhance each other's capacity to act. These actors share resources and cooperate on an equal basis to mutually expand resources and the ability to act. Integrated empowerment assumes that power is contextual, entangled, and relativistic as a phenomenon. Instead of trying to maximise imagined 'power', actors work together with a view to improve the entire ecosystem they share. It is considered a system-wide phenomenon, which in the end improves the health of the entire ecosystem and is beneficial to all the entities within the system.

\subsection{Authorisation and powerlessness}

Authorisation-based empowerment appears to be the most common interpretation of the phenomenon. Historically, empowerment represented direct authorisation wherein a person with authority (e.g., with sovereignty) imparted power to someone else for a certain purpose. The word 'impow'rd', in this sense, appeared in John Milton's Paradise Lost in 1667. The connotation 'authorising and/or licensing' seems to be as old as humanity, whereas its modern form is known to have been in usage since at least 1849 
(Lincoln et al., 2002). Oxford English Dictionary lists similar meanings of to empower: "to invest legally or formally with power or authority; to impart or bestow power to an end or for a purpose, and to gain or assume power over". Within political studies, the sense of authorisation-based empowerment was imbued in the notion of 'powerlessness', wherein it was primarily understood as an overall lack of individual or communal skills to create beneficial outcomes within dependency-based relations (Friedmann, 1992; Regalado, 1988). Here, empowerment meant the reduction of powerlessness, while it was assumed that more political participation of powerless groups, such as the poor or ethnic minorities, would correct the problematic situation of power imbalance (Banducci et al., 2004; Friedmann, 1992; Regalado, 1988). In this context, empowerment also meant assisting the disadvantaged, oppressed, and less fortunate layers of the population and enabling them to acquire increased political power (Regalado, 1988; Weissberg, 1999; West, 1990; Banducci et al., 2004).

\subsection{From micro to macro context}

The limitations of authorisation-based empowerment soon became clear. For instance, Weissberg (1999) reviewed a variety of viewpoints on political empowerment: African-American political action, community psychology, militant feminism, participatory democracy, and anti-big-government empowerment. He critiqued these viewpoints on the basis that power does not represent an end in itself, but only a means for personal or community betterment, while arguing that empowerment would only benefit people or communities if they could gain requisite competency, skills, and knowledge on how to adequately use newly acquired power and authority. Lincoln et al. (2002) reviewed a wide range of management empowerment literature and concluded that empowerment became "a floating concept, which means different things in different organizations and further(more), means different things to different people within organizations" (p.287).

In an organisational context, empowerment stems from two types of processes:

a those that enable an organisation's members to attain individual empowerment, giving rise to an empowering organisation

b those that enable organisations to better coexist and deal with other organisations, resulting in an empowered organisation (Zimmerman, 1995; Peterson and Zimmerman, 2004).

Similarly, empowerment in communities refers to groups of actors working together to collectively improve the quality of life of an entire community (Pigg, 2002; Zimmerman, 1995). Community psychologists argued that empowerment is represented in the improved quality of relationships between the unit of analysis (e.g., the individual or the organisation) and the broader environment, irrespective of intra-power dynamics (Rappaport, 1987; Zimmerman, 1995). Such empowerment is structural, as it is more about how entities gain mastery in dealing with environmental forces, which broadens the understanding of the concept. 


\subsection{From power transfer to mutual enhancement}

In a political context, West (1990) pointed out that empowerment must not be merely understood as a 'power grab' or the oppressed wrestling power away from the dominant. Rather, empowerment should be seen as a process of creating a fair society in which oppressive power is eradicated, and the power of various groups is more or less balanced. Similarly, within community psychology, Pigg (2002) pointed out that one can hardly transfer actual power. Instead, power resources are transferred through mutual and social empowerment. These interpretations were about establishing helping systems that empower those who cannot empower themselves. Furthermore, researchers in women's studies emphasised the relational aspect of empowerment, which is based on such notions as benevolence, compassion, companionship, cooperation, and consensus (Goodrich, 1991a, 1991b; Miller, 1976; Darlington and Mulvaney, 2002). Accordingly, empowerment was defined as a process of "using one's power to empower another increasing the other's resources, capabilities, effectiveness, and ability to act" [Goodrich, (1991a), p.38]. While eschewing a masculine understanding of power grounded in perceived patriarchal hierarchies, feminist researchers emphasised feminine aspects of the process - reciprocity, dialogue, and interactivity - which are to be approached in neither authoritarian nor overly intrusive ways.

To summarise, each discipline conceptualises empowerment from a variety of perspectives, yet the underlying theme of empowerment as a phenomenon that enables individuals, communities, and organisational employees to have a sense of control over and purpose in life events remains the same. These perspectives also assume the presence of a power ladder wherein certain members of the society have the ability (i.e., resources) to empower those who lack the abilities (i.e., resources) to achieve a status of autonomy or sovereignty or the outcome known as empowerment. All of these perspectives are seemingly operating at the micro-level domain within the given ecosystem.

\section{Empowerment perspectives in marketing/consumption studies}

Within marketing disciplines, empowerment has been studied from several broad perspectives: customer service, consumer power, macro-trends and market practices (Buehler and Maas, 2018; McShane and Sabadoz, 2015; Montecchi and Nobbs, 2018; Pranic and Roehl, 2012; Pires et al., 2005; Shaw, 2007; Watheiu et al., 2002). Table 2 summarises the different conceptual variants of empowerment perspectives in marketing. The customer service perspective represents a direct extension of the authorisation-based empowerment model to the customer service context: empowering customer contact or front-line service employees to deliver better service experiences (Bowen and Lawler, 1995; Chebat and Kollias, 2000; Kumar and Pansari, 2016; Raub and Robert, 2013). This tendency is reflected in Chebat and Kollias's (2000) definition of empowerment: “... a situation in which a manager gives employees (e.g., customer contact personnel) the discretion to make day-to-day decisions about job-related activities" (p.68). Chebat and Kollias's study showed that empowering customer contact employees leads to lower levels of role conflict/ambiguity and higher levels of self-efficacy, job satisfaction, and adaptability perceptions, while these perceptions, in turn, mediate the positive impact of empowerment on employees' prosocial behaviour. 
Table 2 Empowerment perspectives in the marketing literature

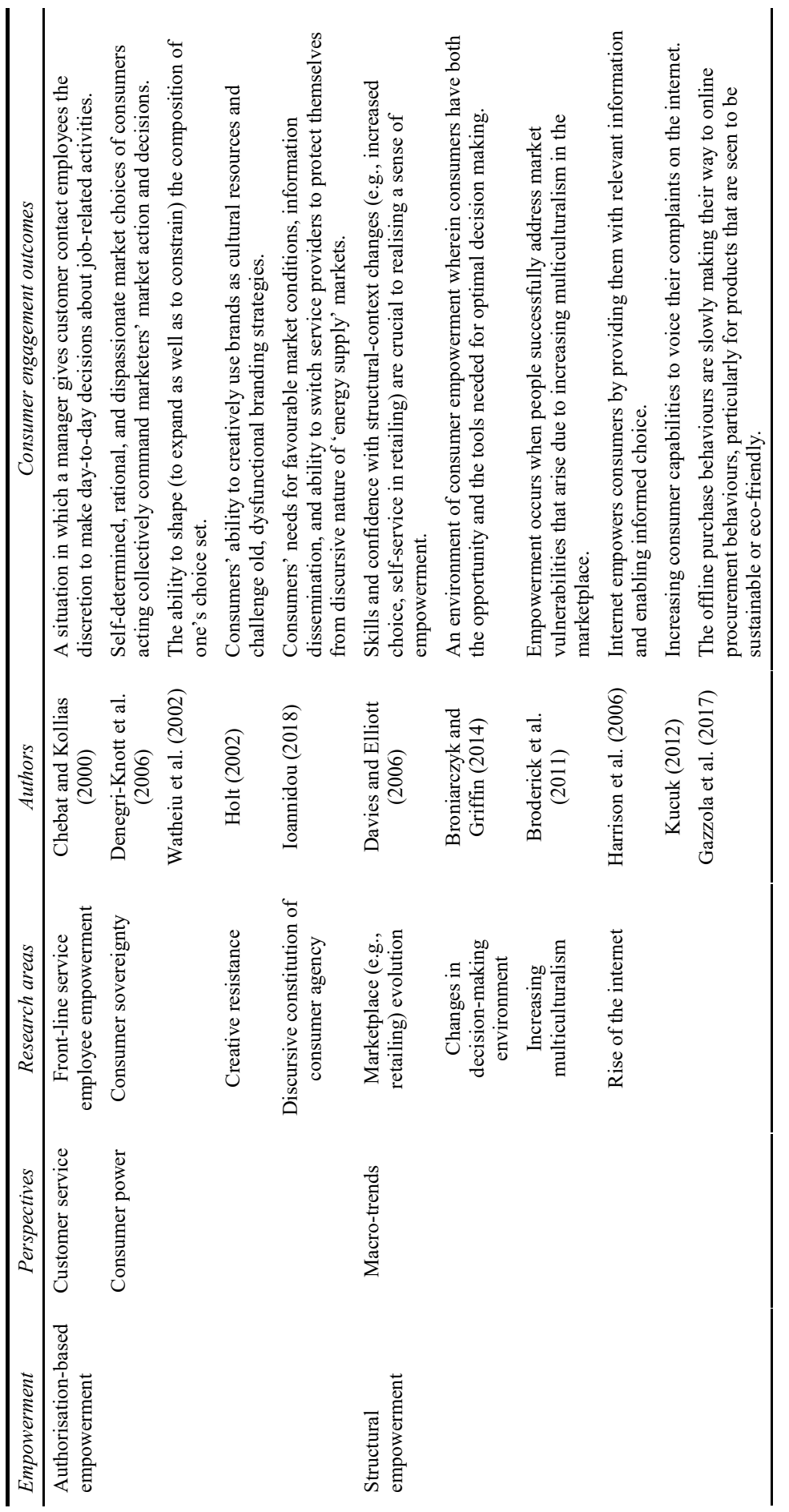


Table 2 Empowerment perspectives in the marketing literature (continued)

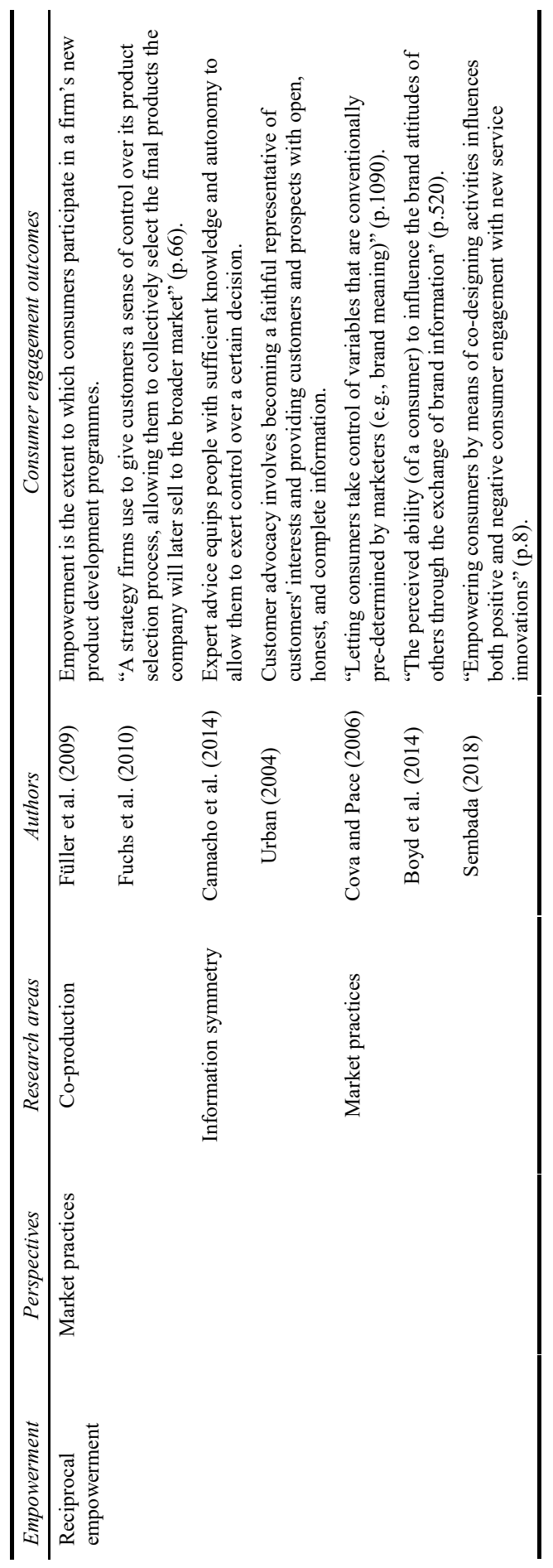


The consumer power perspective extends the authorisation-based empowerment model to the domain of marketer-consumer relationships. This includes research on consumer sovereignty (Denegri-Knott et al., 2006; Henry, 2010; Hirschman, 1970; Kucuk, 2012; Moraes et al., 2011), creative resistance (Holt, 2002; Murray and Ozanne, 1991; Firat and Venkatesh, 1995), and discursive constitution of consumer agency (Denegri-Knott et al., 2006). These streams of research deal with ways of how consumer power can be increased vis-à-vis marketers. The consumer sovereignty stream stresses that individual consumers can improve their sovereignty if they act in self-determined, rational, and dispassionate ways (Henry, 2010). It is also argued that consumer sovereignty can be enhanced via exit or voice strategies (Hirschman, 1970; Kucuk, 2012), collective consumer action such as consumer boycotts and consumerist movements (Denegri-Knott et al., 2006; Nelson, 2002), collective purchase power (Moraes et al., 2011), and consumer protection laws (Delgadillo, 2013). Watheiu et al. (2002) operationalise consumer sovereignty as "the consumer's ability to specify and adjust the choice context" (p.299) and show that it creates positive subjective feelings of increased control.

Echoing structural empowerment meanings, the macro-trends perspective attributes empowerment to changing market conditions (Broderick et al., 2011; Broniarczyk and Griffin, 2014; Davies and Elliott, 2006; Markus and Schwartz, 2010). Focusing on macro changes, Davies and Elliott (2006) argue that marketplace evolution, such as historical development in retailing practices and increased merchandise variety and self-service, results in empowered consumers. Similarly, changes in the decision-making environment, such as greater choice possibilities and greater information opportunities, lead to the same effect, albeit causing increased decision-making difficulty (Broniarczyk and Griffin, 2014; Markus and Schwartz, 2010). Broderick et al. (2011) found that the expansion of multicultural marketplaces creates transient consumer vulnerability, while better social relationships, as an antidote to such a trend, empower consumers. Moreover, the development of the Internet has also been seen as the main driver of consumers acquiring more market power (Harrison et al., 2006; Krishnamurthy and Kucuk, 2009; Kucuk, 2012; Pires et al., 2005; Urban, 2004; Wolfinbarger and Gilly, 2001).

On the other hand, reciprocal empowerment meanings are echoed in the market practices perspective, which focuses on processes such as co-production and value co-creation (Büttgen et al., 2012; Füller et al., 2009), promotion of information symmetry (Camacho et al., 2014; Urban, 2004), and consumer-driven practices (Boyd et al., 2014; Cova and Pace, 2006). It is also operationalised as a risk reduction strategy by firms where their consumers are given equal voice in the transactions as well as in the decision-making processes (Buehler and Maas, 2018; Sembada, 2018). Although co-production was seen as a step towards mutual support, some researchers tended to fall back to the mainstream view of the authorisation-based model. For example, Fuchs et al. (2010) defined empowerment as the "strategy firms use to give customers a sense of control over its product selection process, allowing them to collectively select the final products the company will later sell to the broader market" (p.65). From this perspective, the empowering process is governed by market actors who are given opportunities by firms to control their destiny and make decisions that affect their lives.

To summarise, it is evident that the existing research on empowerment predominantly focuses on the three (upper-left, upper-right, lower-left) quadrants of the proposed empowerment matrix (Table 1). It is apparent that the basic terminology of the 
empowerment discourse tends to harbour the latent empowerment-as-authorisation meaning. From the resource integration perspective, then, it would be plausible to assume that market actors are powerless when engaged in the process of consumption, but once the same exchange concept becomes conceptualised as co-creative, their power increases manifold. In other words, conceptually, if value co-creation as resource integration involves consumption and production processes happening at the same time, then this leads to the paradox of disempowerment and empowerment occurring simultaneously. This would make empowerment a confounding outcome if it were ever achieved, and one in which the confusing reality (paradoxically) stems from its inherent dependency on the traditional views of understanding empowerment mostly at the micro level. Therefore, it is argued that the service ecosystems view is more in line with integrated empowerment when compared to meanings of empowerment that solely focus on the individual actor's power and the individual actor's ability to exercise that power over others at individual, communal, and institutional levels.

\section{Service ecosystem-based interpretive frame(s)}

Systems researchers have argued that the nature of higher-order events in a complex system cannot be deduced from laws derived at the level of the system's components, while a simple aggregation of the components fails to deliver a proper understanding of the system (von Bertalanffy, 1950). Complex systems thinking is about understanding through a continuous process of sense-making, which is different from the typical scientific explanation process (Hudson and Ozanne, 1988). By analogy, we submit that service ecosystems are not linear, one-way service delivery contexts made up of producers and customers (Lusch and Vargo, 2015; Vargo and Akaka, 2012). The service dominant logic postulates that service delivery is the essence of market exchange and that the marketplace is a collection of dynamic networks of service-for-service relationships (Vargo and Lusch, 2004, 2008; Vargo and Akaka, 2012).

Service is defined as the creative use of available resources to benefit others (Vargo and Akaka, 2012), while service system is conceptualised as "a dynamic value co-creation configuration of resources, including people, organizations, shared information (language, laws, measures, methods), and technology" [Spohrer et al., (2008), p.5]. Service ecosystems refer to "relatively self-contained self-adjusting systems of resource-integrating actors connected by shared institutional logics and mutual value creation through service exchange" [Lusch and Vargo, (2015), p.161]. The service ecosystems perspective emphasises the dynamic and iterative nature of service systems; multiple interrelated instances of service creation and resource application simultaneously interact with the temporal and spatial structure of the whole system, which in turn determines how subsequent instances of service provision or co-creation are performed (Vargo and Akaka, 2012; Vargo and Lusch, 2011a). At the same time, loosely coupled components of the system respond to changes in the external environment, and such response is seen to be continuous, self-adjusting, and adaptive. In other words, loose relationships among components as well as structural constraints configure ways through which components gradually adjust to a variety of environmental changes (Vargo and Akaka, 2012). 
One of the important insights of the service ecosystems perspective is that it eschews the 'producer-consumer' divide, or in a service context, the service 'provider-customer' divide (Vargo and Lusch, 2011a). As an alternative, it offers a more inclusive view of the marketplace where the resource integrating actors (including marketers, consumers, and key stakeholders) interact with other actors for the purpose of mutual service provision through mutual value creation (Vargo and Lusch, 2011b). The assumption is that value is simultaneously generated when actors engage in various market activities, including the instances of 'consuming', 'producing' and 'integrating', while participating in resource integrating networks ( $\mathrm{Li}$ et al., 2017). Hence, it is suggested that in such instances, empowerment must happen as mutual-support-providing enablement, which is likely dependent on mutual participation for achieving an optimal outcome for every participant of the given service ecosystem.

\section{Integrated empowerment}

The macro-view of markets as service ecosystems involving a multiplicity of social actors working within relational networks to generate mutual services motivates a richer conceptualisation of empowerment (Gummesson, 2006; Layton, 2007; Lusch and Vargo, 2015). This is evident in the ever-changing patterns of service provisioning that have spanned four decades, starting with firm-centred organisations slowly evolving into open network facilitators, and culminating in integrated empowerment becoming a key component of service deployments (Fehrer et al., 2018). Table 3 outlines conceptual differences between the traditional views of empowerment (authorisation-based empowerment, structural empowerment, and reciprocal empowerment) and the proposed view of integrated empowerment, which is based on a service ecosystems view. This is followed by an outline of some of the nuances of exploring empowerment through the lens of a service ecosystems perspective with some reference to the need for further research.

\subsection{Social actor motives}

As a matter of fact, the systems-view of empowerment is not new. Seminal research by Alderson $(1957,1964)$ predates modern developments by more than a half century. Alderson's focus was on the relationships of organised behavioural systems which were seen to comprise interrelated individual activities. Alderson (1957) talked about power systems which co-constituted elements of behavioural systems (along with other elements such as communication, inputs/outputs, and internal/external adjustments). According to Alderson, a behavioural system cannot operate without allowing for its own power system, which represents relative status positions conferred by institutions. These status positions would determine not only the extent of access to available resources but also predefined resource rationing. In addition, Alderson described the power principle, according to which action within a behavioural system could be understood as a move toward improving the whole system's capacity to act (e.g., capacity to grow, adapt, and evolve). 
Table 3 Empowerment perspectives

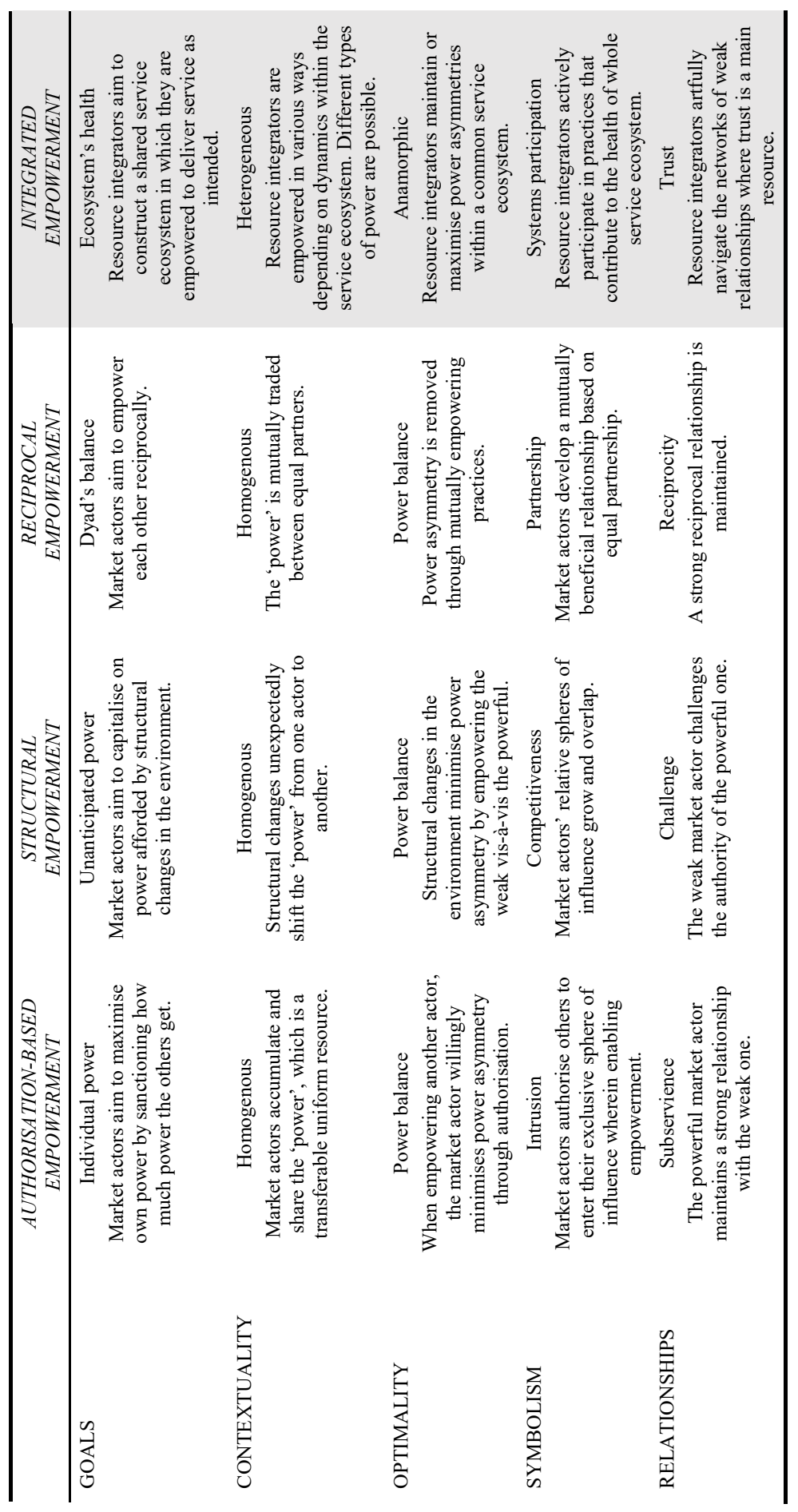


As empowerment presupposes the existence of relationships, the understanding of power as the pertaining characteristic of a market agent is not tenable (Foucault, 1980). To be consistent, power relationships must be seen as a systems occurrence, namely the dialectical relation between power struggles at the core (e.g., between industry incumbents) and empowering potential at the periphery (Cheater, 2003). In other words, empowerment occurs at a meta-systems level: a change in inter-actor relationships and their relative status positions within the marketing system would increase or decrease the system's ability to maintain its continuous emergence/re-emergence. From this perspective, attempts at maximising control and power within the boundaries of a single firm can be self-destructive, as it might erode the general 'health' of an ecosystem within which the firm operates. At this juncture, we would like to refer to W.L. Gore's 'lattice' organisation and Google's 'brink of chaos' model designed to encourage and amplify ecosystem-wide creativity and innovation.

\subsection{Contextuality of empowerment}

Previous research alludes to the heterogeneous nature of power (Denegri-Knott et al., 2006) as it is argued that power is not a particular type of 'substance' that can be shifted from one social actor to another. Rather, power should be seen as a heterogeneous, fluid, context-specific occurrence. The view that power can be 'accumulated', 'exchanged', 'recovered' or 'shifted' is not commensurable within the systems view (Cheater, 2003; Foucault, 1980). If one chooses to focus on firm-customer dyads, empowerment can have a different essence, depending on the different dimensions of such relationships. For example, the top-down perspective can give a different picture compared to the bottom-up perspective. From the former perspective, managers might believe that they are 'empowering' the customer by making co-production within service delivery possible. However, the bottom-up perspective sees the customers dominating the relationship whereby they institutionalise the context in which the firm's 'co-creation' attempt is accepted as normal. This view parallels the notion of power by 'popular authority' (Cheater, 2003). Here, the customer (i.e., social actor) becomes both the object and subject of empowering action. The situation is cyclical as market actors (i.e.., customers) empower firms within the institutional sphere by assembling the firms' empowerment practices (which occur within the co-creation sphere) that are meaningful and acceptable. Here, we observe at least two different types of empowerment phenomena that tend to flow within business networks in opposite directions.

Within service ecosystems, empowerment occurs when resulting institutions improve social actors' capacity to act, for example, through creative resource integration. By ensuring actors' freedom in flexibly integrating resources in idiosyncratic ways, the system acts as a dissipative structure. It attracts people with various skills and knowledge, through the mechanisms of engagement and participation, and empowers them to come up with unique, context-specific solutions to their market-based problems. This sets out the need for further research to explore empowerment within the service ecosystems framework, beyond the somewhat static and dyadic conceptualisations inherent to the traditional view of empowerment that are found in extant literature. 


\subsection{Anamorphic nature of empowerment}

Service ecosystems pertain to human activity and represent complex contrived structures that dynamically emerge in complex ways (Katz and Kahn, 1966; Monieson, 1981). Therefore, the understanding of such systems must be informed by contrasts to mechanical and deterministic systems (von Bertalanffy, 1950; Katz and Kahn, 1966). Applying the principles of general systems theory (von Bertalanffy, 1950), the complex nature of power within systems can be understood as an anamorphic phenomenon, that is, as a phenomenon with the general tendency toward complexity that moves the system away from the equilibrium state. Hence, in the marketing literature, the assumed equilibrium such as 'power equality' must be reconceptualised should researchers seek a better re-alignment with complex systems thinking. This is an important point, all the more so because the desirability of restoring power balance tends to be implied in the current marketing literature as empowerment (Wolf et al., 2015).

An in-depth understanding of complex dynamics in service ecosystems may shed light on the power quandary: Are the market actors claiming to empower other actors actually in the business of consolidating their unique status of 'power-granting' institutions? What is the precise power relation of the 'empowerer' to those experiencing the lack of resources? (Foucault, 1980). Does it not render the powerful even more powerful as the 'empowered' actors would end up becoming reliant on empowerment initiatives? Taking the whole systems view, we observe that current empowerment initiatives and the accompanying presumption of the desirability of power parity have become a new symbolic context that masks mechanisms through which power disparity is continually maximised. Hence, Lincoln et al. (2002) expressed frustration that empowerment in organisations has become a 'symbolic exercise'.

\subsection{Empowerment and systemic viability}

What does it mean to be empowered from the service ecosystems perspective? As we are concerned with improving a service ecosystem's power to maintain its coherence, relevance, and a unique position in society (i.e., power to all), we argue that the intra-systems focus on empowerment must involve the continuous enablement of system-wide participation. Participation ensures a steady inflow of resources (e.g., skills, knowledge, know-how, and technology), and continuous co-creative re-configuration of these resources, which are the key processes in a dissipative structure. It would be limiting to see participation from the micro perspective and conceptualise it simply as 'intrusion' into another's sphere of dominance. Rather, it must be seen as a general goal-oriented action that aims to nurture the whole ecosystem as if it were the commons. Participation must be recognised as a form of collaboration, primarily based on the ethos of benevolence, mutuality, interconnectedness, and reciprocity (Achrol and Kotler, 1999; Håkansson and Snehota, 2006).

Through participation, market actors continually make and re-make markets, continuously strive for rewards, and uphold market commitments/responsibilities. For example, the success of service ecosystems enabled by companies like Alibaba, Facebook, YouTube, LEGO (Mindstorm series), and Google (Android OS) is based on enabling users to apply their knowledge and skills to benefit the company as well as other users (Leadbeater, 2008). These companies tend to primarily invest in the general improvement of the service ecosystems and offer service platforms gratis while enabling 
users to better integrate and re-configure resources available to them (Fehrer et al., 2018; Fu et al., 2017; Gamble et al., 2017). Hence, monetary exchanges that generate profit become a type of reward for system-wide empowerment 'done well' (Varey, 2011).

\section{Discussion}

Conceptualising the occurrence of empowerment from either the perspective of the service provider or through the lens of the service receiver is an outmoded argument, particularly in the light of prevalent discussion around the service ecosystems view. The ecosystems discussion points to a much more complex, interdependent network phenomenon of integrated empowerment which when operationalised could be beneficial for all the players that constitute the resultant system. Any attempts to achieve the power balance or confer some power to others may not be the best way of empowering the whole service ecosystem. Based on the initial conceptualisation of integrated empowerment, we submit that service, as a holistic phenomenon, is in fact enabled/facilitated by empowerment. We believe that service provisioning would not be possible without integrated empowerment. This argument is in stark contrast to the traditional view that service is enhanced by empowerment. Exploring the nuances of processes that lead to integrated empowered outcomes in service ecosystems remains a fascinating as well as an intriguing challenge. This is likely to open up new possibilities to explore the phenomenon from a systems (meta-theoretical) perspective (Vargo and Lusch, 2017).

The contextuality of empowerment under the traditional view is largely understood as a competitive struggle to capture value, that is, as an ongoing battle for a bigger share in the industry profit margin (Porter, 2008). In such a scenario, it is important for industry players to maximise 'power' that is understood as a capacity to have negotiating leverage relative to other industry players, including the markets themselves. Power comes in various forms, and resource integrators have to seamlessly become part of the process of sharing and creating value in the relationships. Depending on the position and role they play in the ecosystem, resource integrators dynamically empower each other through different channels. In maximising power in one avenue, resource integrators create potentialities in another, and these potentialities, as symbolic fields, become a new source of power for other resource integrators. (Kadirov and Varey, 2011).

The service ecosystems perspective emphasises the participatory character of empowerment. We would like to draw attention to the current challenges and to a broad-based discussion centred around operationalising integrated empowerment strategies within the service ecosystems that are increasingly becoming reliant on platform-based business models (Fu et al., 2017; Gamble et al., 2017). The platformisation of businesses involves a multiplicity of social actors who interact with each other in order to achieve system-wide transactions, moving away from the classical firm-centred logics of doing business (Porter, 2008; Weiland et al., 2017). These social actors adorn various identities, at times within and sometimes outside of the given ecosystems, to work collaboratively in order to participate and contribute to the episodes of service provisioning. We propose these actor-actor service exchanges in fact offer an opportunity for all of the actors involved in the ecosystem to provisionally intrude into each other's spheres of power/authority/control and share resources to bring about outcomes that protect or perhaps enhance the overall health of the ecosystem. All of this 
is possible only when the actor-actor engagements are able to operationalise integrated empowerment modalities throughout the given ecosystem.

\section{Evolving research agenda}

We accept that service ecosystems are highly complex entities and that investigating occurrences of the system-wide phenomenon (i.e., empowerment) remains a daunting challenge. This paper offers an insightful discussion to promote further research to enrich the debate and the current understandings of services research and theory. At this juncture, we would like to present a few research opportunities to encourage further investigation. One of the first issues worth considering is how empowerment should be conceived, that is, should empowerment as an outcome be investigated as a top-down or bottom-up phenomenon or perhaps a joint endeavour between all the social actors that constitute the ecosystem itself. The second issue worth investigating is centred on the idea of empowerment strategies and how they are to be operationalised. When service provisioning becomes a level playing field for all of the social actors involved in an ecosystem, then the distinction between the service provider (i.e., the power-broker) and the service receiver (i.e., the customer) fades away. It would be interesting to explore how the power-broker identity adorned by the service provider (i.e., the social actor) metamorphoses from being the controller to becoming more of system-wide facilitator for achieving empowered outcomes for all. It will be even more crucial to understand if and how integrated empowerment plays a role in the transformation of identities. A genuine attempt at exploring these issues would certainly add depth to the extant literature as well as to the current understandings of the phenomenon called empowerment.

\section{Acknowledgements}

We would like to show our sincere gratitude to Professor John G. Oetzel and Professor Suvi Nenonen for providing insightful commentary on our conceptual paper in its early days.

\section{References}

Achrol, R.S. and Kotler, P. (1999) 'Marketing in the network economy', The Journal of Marketing, Vol. 63, No. 4, Suppl. 1, pp.146-163.

Akhavannasab, S., Dantas, D.C. and Senecal, S. (2018) 'Consumer empowerment in consumer-firm relationships: conceptual framework and implications for research', $A M S$ Review, Vol. 8, Nos. 3-4, pp.214-227.

Alderson, W. (1957) Marketing Behaviour and Executive Action: A Functionalist Approach to Marketing Theory, R.D. Irwin, Homewood, IL.

Alderson, W. (1964) 'A normative theory of marketing systems', Theory in Marketing, pp.92-108, Richard Irwin, Homewood.

Banducci, S.A., Donovan, T. and Karp, J.A. (2004) 'Minority representation, empowerment, and participation', The Journal of Politics, Vol. 66, No. 2, pp.534-556. 
Barile, S., Lusch, R., Reynoso, J., Saviano, M. and Spohrer, J. (2016) 'Systems, networks, and ecosystems in service research', Journal of Service Management, Vol. 27, No. 4, pp.652-674.

Bekin, C., Carrigan, M. and Szmigin, I. (2006) 'Empowerment, waste and new consumption communities', International Journal of Sociology and Social Policy, Vol. 26, Nos. 1-2, pp.32-47.

Ben Ayed, M. and El Aoud, N. (2017) 'The patient empowerment: a promising concept in healthcare marketing', International Journal of Healthcare Management, Vol. 10, No. 1, pp.42-48.

Bernoff, J. and Schadler, T. (2010) Empowered: Unleash Your Employees, Energize Your Customers, Transform Your Business, Harvard Business Review Press, Boston, MA.

Bowen, D.E. and Lawler III, E.E. (1995) 'Empowering service employees', MIT Sloan Management Review, Vol. 36, No. 4, pp.73-84.

Boyd, D.E., Clarke, T.B. and Spekman, R.E. (2014) 'The emergence and impact of consumer brand empowerment in online social networks: a proposed ontology', Journal of Brand Management, Vol. 21, No. 6, pp.516-531.

Broderick, A.J., Demangeot, C., Adkins, N.R., Ferguson, N.S., Henderson, G.R., Johnson, G., ... and Zúñiga, M.A. (2011) 'Consumer empowerment in multicultural marketplaces: navigating multicultural identities to reduce consumer vulnerability', Journal of Research for Consumers, No. 19 [online] http://jrconsumers.com/Academic_Articles/issue_19/ Multicultural_academic5.pdf

Broniarczyk, S.M. and Griffin, J.G. (2014) 'Decision difficulty in the age of consumer empowerment', Journal of Consumer Psychology, Vol. 24, No. 4, pp.608-625.

Buehler, P. and Maas, P. (2018) 'Consumer empowerment in insurance: effects on performance risk perceptions in decision making', International Journal of Bank Marketing, Vol. 36, No. 6, pp.1073-1097.

Büttgen, M., Schumann, J.H. and Ates, Z. (2012) 'Service locus of control and customer coproduction: the role of prior service experience and organizational socialization', Journal of Service Research, Vol. 15, No. 2, pp.166-181.

Camacho, N., De Jong, M. and Stremersch, S. (2014) 'The effect of customer empowerment on adherence to expert advice', International Journal of Research in Marketing, Vol. 31, No. 3, pp.293-308.

Castelfranchi, C. (2003) 'The micro-macro constitution of power', Protosociology, Vol. 18, No. 1, pp.208-265.

Chandler, J.D. and Vargo, S.L. (2011) 'Contextualization and value-in-context: how context frames exchange', Marketing Theory, Vol. 11, No. 1, pp.35-49.

Cheater, A. (Ed.) (2003) The Anthropology of Power: Empowerment and Disempowerment in Changing Structures, Routledge, London, UK.

Chebat, J-C. and Kollias, P. (2000) 'The impact of empowerment on customer contact employees' roles in service organizations', Journal of Service Research, Vol. 3, No. 1, pp.66-81.

Christens, B.D. (2012) 'Toward relational empowerment', American Journal of Community Psychology, Vol. 50, Nos. 1-2, pp.114-128.

Conger, J.A. and Kanungo, R.N. (1988) 'The empowerment process: Integrating theory and practice', The Academy of Management Review, Vol. 13, No. 3, pp.471-482.

Cova, B. and Pace, S. (2006) 'Brand community of convenience products: new forms of customer empowerment - the case 'my Nutella The Community',,. European Journal of Marketing, Vol. 40, Nos. 9-10, pp.1087-1105.

Darlington, P.S.E. and Mulvaney, B.M. (2002) 'Gender, rhetoric, and power: toward a model of reciprocal empowerment', Women's Studies in Communication, Vol. 25, No. 2, pp.139-172.

Davies, A. and Elliott, R. (2006) 'The evolution of the empowered consumer', European Journal of Marketing, Vol. 40, Nos. 9-10, pp.1106-1121. 
Delgadillo, L.M. (2013) 'An assessment of consumer protection and consumer empowerment in Costa Rica', Journal of Consumer Policy, Vol. 36, No. 1, pp.59-86.

Denegri-Knott, J., Zwick, D. and Schroeder, J. (2006) 'Mapping consumer power: an integrative framework for marketing and consumer research', European Journal of Marketing, Vol. 40, Nos. 9-10, pp.950-971.

Fehrer, J.A., Woratschek, H., Germelmann, C.C. and Brodie, R.J. (2018) 'Dynamics and drivers of customer engagement: within the dyad and beyond', Journal of Service Management, Vol. 29, No. 3, pp.443-467.

Firat, A.F. and Venkatesh, A. (1995) 'Liberatory postmodernism and the reenchantment of consumption', Journal of Consumer Research, Vol. 22, No. 3, pp.239-267.

Foucault, M. (1980) Power/Knowledge: Selected Interviews and Other Writings, 1972-1977, Pantheon Books, New York, NY.

Friedmann, J. (1992) Empowerment: The Politics of Alternative Development, Blackwell Publishers, Cambridge, MA.

Frow, P., McColl-Kennedy, J.R., Hilton, T., Davidson, A., Payne, A. and Brozovic, D. (2014) 'Value propositions: a service ecosystems perspective', Marketing Theory, Vol. 14, No. 3, pp.327-351.

Fu, W., Wang, Q. and Zhao, X. (2017) 'The influence of platform service innovation on value co-creation activities and the network effect', Journal of Service Management, Vol. 28, No. 2, pp.348-388.

Fuchs, C., Prandelli, E. and Schreier, M. (2010) 'The psychological effects of empowerment strategies on consumers' product demand', Journal of Marketing, Vol. 74, No. 1, pp.65-79.

Füller, J., Mühlbacher, H., Matzler, K. and Jawecki, G. (2009) 'Consumer empowerment through internet-based co-creation', Journal of Management Information Systems, Vol. 26, No. 3, pp.71-102.

Gamble, J.R., Brennan, M. and McAdam, R. (2017) 'A rewarding experience? Exploring how crowdfunding is affecting music industry business models', Journal of Business Research, Vol. 70, No. 1, pp.25-36.

Gazzola, P., Colombo, G., Pezzetti, R. and Nicolescu, L. (2017) 'Consumer empowerment in the digital economy: availing sustainable purchasing decisions', Sustainability, Vol. 9, Vol. 5, p.693.

Goodrich, T.J. (1991) 'Women, power, and family therapy: what's wrong with this picture?', Journal of Feminist Family Therapy, Vol. 3, Nos. 1-2, pp.5-37.

Goodrich, T.J. (1991a) 'Women, power and family therapy: what's wrong with this picture?', in Goodrich, T.J. (Ed.): Women and Power: Perspectives for Family Therapy, pp.3-35, Norton, New York, NY.

Gummesson, E. (2006) 'Many-to-many marketing as grand theory: a Nordic school contribution', in Lusch, R.F. and Vargo, S.L. (Eds.): The Service-Dominant Logic of Marketing: Dialog, Debate, and Directions, pp.339-353, M.E. Sharpe, New York, NY.

Håkansson, H. and Snehota, I. (2006) 'No business is an island' 17 years later', Scandinavian Journal of Management, Vol. 22, No. 3, pp.271-274.

Harrison, T., Waite, K. and Hunter, G.L. (2006) 'The internet, information and empowerment', European Journal of Marketing, Vol. 40, Nos. 9-10, pp.972-993.

Henry, P.C. (2010) 'How mainstream consumers think about consumer rights and responsibilities', Journal of Consumer Research, Vol. 37, No. 4, pp.670-687.

Hirschman, A.O. (1970) Exit, Voice, and Loyalty: Responses to Decline in Firms, Organizations, and States, President and Fellows of Harvard College, Cambridge, MA.

Holosko, M.J., Leslie, D.R. and Cassano, D.R. (2001) 'How service users become empowered in human service organizations: the empowerment model', International Journal of Health Care Quality Assurance, Vol. 14, No. 3, pp.126-133. 
Holt, D.B. (2002).'Why do brands cause trouble? A dialectical theory of consumer culture and branding', Journal of Consumer Research, Vol. 29, No. 1, pp.70-90.

Hudson, L.A. and Ozanne, J.L. (1988) 'Alternative ways of seeking knowledge in consumer research', Journal of Consumer Research, Vol. 14, No. 4, pp.508-521.

Ioannidou, M. (2018) 'Effective paths for consumer empowerment and protection in retail energy markets', Journal of Consumer Policy, Vol. 41, No. 2, pp.135-157.

Kadirov, D. and Varey, R. (2011) 'Symbolism in marketing systems', Journal of Macromarketing, Vol. 31, No. 2, pp.160-171.

Katz, D. and Kahn, R.L. (1966) The Social Psychology of Organizations, Wiley, New York, NY.

Krishnamurthy, S. and Kucuk, S.U. (2009) 'Anti-branding on the internet', Journal of Business Research, Vol. 62, No. 11, pp.1119-1126.

Kucuk, S.U. (2012) 'Can consumer power lead to market equalization on the internet?', Journal of Research for Consumers, Vol. 21, p.1.

Kumar, V. and Pansari, A. (2016) 'Competitive advantage through engagement', Journal of Marketing Research, Vol. 53, No. 4, pp.497-514.

Layton, R.A. (2007) 'Marketing systems - a core macro-marketing concept', Journal of Macromarketing, Vol. 27, No. 3, pp.227-242.

Leadbeater, C. (2008) We-Think: The Power of Mass Creativity, Profile Books Limited, London, UK.

Li, L.P., Juric, B. and Brodie, R.J. (2017) 'Dynamic multi-actor engagement in networks: the case of United Breaks Guitars', Journal of Service Theory and Practice, Vol. 27, No. 4, pp.738-760.

Lincoln, N.D., Travers, C., Ackers, P. and Wilkinson, A. (2002) 'The meaning of empowerment: the interdisciplinary etymology of a new management concept', International Journal of Management Reviews, Vol. 4, No. 3, pp.271-290.

Lusch, R.F. and Vargo, S.L. (2015) The Service-Dominant Logic of Marketing: Dialog, Debate, and Directions, Routledge, New York NY.

Lusch, R.F., Vargo, S.L. and Tanniru, M. (2010) 'Service, value networks and learning', Journal of the Academy of Marketing Science, Vol. 38, No. 1, pp.19-31.

Malhotra, A. and Schuler, S.R. (2005) 'Women's empowerment as a variable in international development', in Narayan, D. (Ed.): Measuring Empowerment: Cross-Disciplinary Perspectives, pp.71-88, World Bank, Washington, DC.

Mandlik, M.A., Glynn, M. and Hyde, K. (2014) 'Client contribution to professional service delivery: implications for relationship quality', New Zealand Journal of Applied Business Research, Vol. 12, No. 1, p.19.

Markus, H.R. and Schwartz, B. (2010) 'Does choice mean freedom and well-being?', Journal of Consumer Research, Vol. 37, No. 2, pp.344-355.

McShane, L. and Sabadoz, C. (2015) 'Rethinking the concept of consumer empowerment: recognizing consumers as citizens', International Journal of Consumer Studies, Vol. 39, No. 5, pp.544-551.

Miller, J.B. (1976) Toward a New Psychology of Women, Beacon Press, Boston, MA.

Milton, J. (1667) Paradise Lost, Samuel Simmons, London, UK.

Monieson, D.D. (1981) 'Marketing and the theory of dissipative structures', Proceedings of the 1981 American Marketing Association Educators Conference, August, No. 47.

Montecchi, M. and Nobbs, K. (2018) 'Let it go: consumer empowerment and user-generated content - an exploratory study of contemporary fashion marketing practices in the digital age', Digital Marketing and Consumer Engagement: Concepts, Methodologies, Tools, and Applications, Vol. 2, pp.1106-1129, IGI Global, Hershey, PA.

Moraes, C., Shaw, D. and Carrigan, M. (2011) 'Purchase power: an examination of consumption as voting', Journal of Marketing Management, Vol. 27, Nos. 9-10, pp.1059-1079. 
Murray, J.B. and Ozanne, J.L. (1991) 'The critical imagination: emancipatory interests in consumer research', Journal of Consumer Research, Vol. 18, No. 2, pp.129-144.

Nelson, W. (2002) 'Practice papers all power to the consumer? Complexity and choice in consumers' lives', Journal of Consumer Behaviour, Vol. 2, No. 2, pp.185-195.

Peterson, N.A. and Zimmerman, M.A. (2004) 'Beyond the individual: toward a nomological network of organizational empowerment', American Journal of Community Psychology, Vol. 34, Nos. 1-2, pp.129-145.

Pigg, K.E. (2002) 'Three faces of empowerment: expanding the theory of empowerment in community development', Journal of the Community Development Society, Vol. 33, No. 1, pp.107-123.

Pires, G., Stanton, J. and Stanton, P. (2005) 'Toward a preliminary model of consumer empowerment', Paper presented at the Australia \& New Zealand Marketing Academy Conference, Wellington, New Zealand

Porter, M.E. (2008) On Competition, Harvard Business Review Press. Boston, MA.

Pranic, L. and Roehl, W.S. (2012) 'Rethinking service recovery: a customer empowerment (CE) perspective', Journal of Business Economics and Management, Vol. 13, No. 2, pp.242-260.

Ramani, G. and Kumar, V. (2008) 'Interaction orientation and firm performance', Journal of Marketing, Vol. 72, No. 1, pp.27-45.

Rappaport, J. (1987) 'Terms of empowerment/exemplars of prevention: toward a theory for community psychology', American Journal of Community Psychology, Vol. 15, No. 2, pp.121-148.

Raub, S. and Robert, C. (2013) 'Empowerment, organizational commitment, and voice behavior in the hospitality industry: evidence from a multinational sample', Cornell Hospitality Quarterly, Vol. 54, No. 2, pp.136-148.

Regalado, J. (1988) 'Latino representation in Los Angeles', in Villarreal, R.E., Hernandez, N.G. and Neighbor, H.D. (Eds.): Latino Empowerment: Progress, Problems, and Prospects, p.99, Greenwood Press, New York, NY.

Schulz, A.J., Israel, B.A., Zimmerman, M.A. and Checkoway, B.N. (1995) 'Empowerment as a multi-level construct: perceived control at the individual, organizational and community levels', Health Education Research, Vol. 10, No. 3, pp.309-327.

Sembada, A. (2018) 'The two sides of empowering consumers to co-design innovations', Journal of Services Marketing, Vol. 32, No. 1, pp.8-18.

Shaw, D. (2007) 'Consumer voters in imagined communities', The International Journal of Sociology and Social Policy, Vol. 27, Nos. 3-4, pp.135-150.

Spohrer, J., Anderson, L.C., Pass, N.J., Ager, T. and Gruhl, D. (2008) 'Fundamentals of service science', J. Acad. Market Sci., March.

Urban, G.L. (2004) 'The emerging era of customer advocacy', MIT Sloan Management Review, Vol. 45, No. 2, p.77.

Varey, R.J. (2011) 'A sustainable society logic for marketing', Social Business, Vol. 1, No. 1, pp.69-83.

Vargo, S.L. and Akaka, M.A. (2012) 'Value cocreation and service systems (re) formation: a service ecosystems view', Service Science, Vol. 4, No. 3, pp.207-217.

Vargo, S.L. and Lusch, R.F. (2004a) 'Evolving to a new dominant logic for marketing', Journal of Marketing, Vol. 68, No. 1, pp.1-17.

Vargo, S.L. and Lusch, R.F. (2008) 'Service-dominant logic: continuing the evolution', Journal of the Academy of Marketing Science, Vol. 36, No. 1, pp.1-10.

Vargo, S.L. and Lusch, R.F. (2011a) 'It's all B2B... and beyond: toward a systems perspective of the market', Industrial Marketing Management, Vol. 40, No. 2, pp.181-187.

Vargo, S.L. and Lusch, R.F. (2011b) 'Service-dominant logic: looking ahead', Presentation at the Naples Forum on Service, 14-17 June, Isle of Capri, Italy. 
Vargo, S.L., and Lusch, R.F. (2017) 'Service-dominant logic 2025', International Journal of Research in Marketing, Vol. 34, No. 1, pp.46-67.

von Bertalanffy, L. (1950) 'An outline of general system theory', The British Journal for the Philosophy of Science, Vol. 1, No. 2, pp.134-165.

Watheiu, L., Brenner, L., Carmon, Z., Chattopadhyay, A., Wertenbroch, K., Drolet, A., ... Wu, G. (2002) 'Consumer control and empowerment: a primer', Marketing Letters, Vol. 13, No. 3, pp.297-305.

Weissberg, R. (1999) The Politics of Empowerment, Praeger Publishers, Westport, CT.

West, D. (1990) Authenticity and Empowerment: A Theory of Liberation, Harvester Wheatsheaf, Hemel Hempstead, UK.

Wieland, H., Hartmann, N.N. and Vargo, S.L. (2017) 'Business models as service strategy', J. of the Acad. Mark. Sci., Vol. 45, pp.925-943.

Wieland, H., Polese, F., Vargo, S. and Lusch, R. (2012) 'Toward a service (eco)systems perspective on value creation', International Journal of Service Science, Management, Engineering, and Technology, Vol. 3, No. 3, pp.12-25.

Wolf, M., Albinsson, P.A. and Becker, C. (2015) 'Do-it-yourself projects as path toward female empowerment in a gendered market place', Psychology \& Marketing, Vol. 32, No. 2, pp.133-143.

Wolfinbarger, M. and Gilly, M.C. (2001) 'Shopping online for freedom, control, and fun', California Management Review, Vol. 43, No. 2, pp.34-55.

Zimmerman, M.A. (1995) 'Psychological empowerment: issues and illustrations', American Journal of Community Psychology, Vol. 23, No. 5, pp.581-599.- 